\title{
Giant anal warts
}

Francesk Mulita ${ }^{1}$, Evangelos Iliopoulos ${ }^{1}$, and Ioannis Maroulis ${ }^{1}$

${ }^{1}$ University General Hospital of Patras Holy Mary the Help

April 28, 2020

\begin{abstract}
A 70-year-old male presented with a neglected slow growing anal wart for many years with bleeding. A deep core biopsy of the tumor confirmed a high-grade squamous intraepithelial lesion and carcinoma in situ.
\end{abstract}

\section{Hosted file}

text.docx available at https://authorea.com/users/309614/articles/440720-giant-anal-warts

\section{Hosted file}

FIGURE.tiff available at https://authorea.com/users/309614/articles/440720-giant-anal-warts 